\title{
Klart slut varulvstjut - den litterära pojkhumorn och exemplet Bert
}

\author{
http://urn.kb.se/resolve?urn=urn:nbn:se:sbi-43
}

\begin{abstract}
Literary boy homour and the books about Bert as an example". In this article I outline the roots of boy humour in children's literature. In Swedish tradition this category is intimately associated with the genre "tjuopojksboken"(stories about young rascals). I argue that one important condition for the development of a humour of this kind, are the concept of the boy as a gentle savage, a central character in boyology. A discourse comprising descriptive and prescriptive writing on boyhood across a variety of genres. In Making American Boys (2004) Kenneth B. Kidd shows how the boyologists of the early twentieth century reworked themes and tropes they picked up from the American Boy Book (like Aldrich, Twain, and Tarkington); foremost the idea of the wildness of boys as a necessary step in becoming a man. Another important condition for boy humour is that the stories are told from the boy's perspective, which in turn makes way for different boy's discourses, such as "slanguage". After examining the issue from a historical point-of-view, I turn to Anders Jacobsson's and Sören Olsson's popular books about the boy Bert (23 books between 1987-2010), with focus on the first title Berts dagbok [Bert's diary]. Here I concentrate on three characteristic features: the carnivalesque degrading of the adult world, the grotesque realism (the world interpreted through the boy's bodily experience), and play on words, such as rhymes, puns, jokes and deliberately misreading offoreign and difficult words. My point is that the readers (boys) through channels like this, learn the humorous discourse and that it creates intimate bonds between the narrator and the readers.
\end{abstract}

Keywords: boy humour, boyology, bad boy books, Anders Jacobsson \& Sören Olsson

I Magnus Nordins Blodets röst (2010) återvänder Daniel till barndomshemmets pojkrum: "I Billybokhyllan stod hans Bert- och Suneböcker inträngda mellan 14-tums-teven och Play Station-modulen." (Nordin 2010, 73) Här får vi en komprimerad och effektiv bild av den svenska pojkkultur som har sitt epicentrum kring 1990-talets mitt, 
vars allmängiltighet understryks via den folkhemska IKEA-möbeln. Men trots att Anders Jacobssons och Sören Olssons hjältar har haft ett enormt genomslag, böckerna har sålt i stora upplagor och filmatiserats, har Bert och Sune ägnats ringa uppmärksamhet i litteraturvetenskapliga sammanhang. I exempelvis Ord och bilder för barn och ungdom III. Ungdomslitteraturen (1994) omnämns de parentetiskt (Furuland m.fl. 1994, 299) och i Ann Boglinds \& Anna Nordenstams Från fabler till manga (2010) nämns de inte alls.

Anledningen till det vetenskapliga ointresset kan förklaras med att denna litteratur utgör en i sammanhanget olycklig kombination. Dels sorterar den under populärlitteraturen, vilken har låg status inom litteraturvetenskaplig forskning och historieskrivning, dels handlar det om humor, ett fenomen till vilket en stor del av forskningen har ett ambivalent förhållande. I de flesta fall när komiken studeras ställs den i kontrast till allvar och seriositet - och kommer till korta (se nedan).

För att till viss del söka täcka in denna vita fläck på forskningskartan har jag i artikeln valt att koncentrera mig på Bert och på det jag skulle vilja kalla för pojkhumor. Då forskning på området är sparsam får detta ses som en första sondering, ett försök att ringa in pojkhumorn genom att betrakta den som en diskurs, alltså en helhet av sammanhängande uttryck, utsagor och begrepp som ger en förståelse av världen. Ett sådant betraktelsesätt öppnar naturligtvis upp för undersökningar av filmer, teveprogram, tecknade serier, skämttidningar, anekdotsamlingar och inte minst pojkars muntliga berättande (vitsar, gåtor, roliga historier etc.), men här är det pojkhumorns litterära uttryck som är i fokus.

Syftet med studien är dels att söka Bertböckernas litterära förutsättningar genom att kartlägga det som kallas tjuvpojksboken, en genre som delvis behärskas av den pojkhumoristiska diskursen. Och dels frilägga och studera tre typiska drag av diskursen såsom den uppträder i texterna om Bert: det karnevaliska i form av detroniseringen (förlöjligandet) och grotesken samt språkleken.

I de fall då pojkhumorn legat under lupp märks den tidigare nämnda ambivalensen, i synnerhet då den företräder en humor som brukar betraktas som "låg". När överlärare Lorentz Larson i sin läsvaneundersökning Ungdom läser (1947) ska handskas med det faktum att Richmal Cromptons böcker om Bill tillhör den populäraste läsningen bland svenska pojkar, menar han att det har sin "psykologiska förklaring". Han skriver: "De får nämligen i Bill läsa om sådant som de hjärtans gärna skulle vilja göra men inte har mod till eller inte får. [...] Häri har Bill sitt enda värde - den kan inte räknas till någon 
värdefullare typ av ofogsböckerna - rackartyget är till för sitt eget skull, barnskildringen har ringa värde - det är ofog inte psykologi." (Larson 1947, 27f) Men ska inte en "värdefull" ofogsbok innehålla just ofog och är det inte i sådana fall just detta ofog som är en förutsättning för det Larson kallar en "psykologisk förklaring", det vill säga den (skade-)glädje läsaren känner när Bill förlöjligar vuxenvärlden. (Man kan vidare fråga sig hur noga Larson själv läste böckerna, med tanke på att han påstår att engelska Bill "är en amerikansk pojke").

Hos Larson märks en tydlig nedvärdering av Billböckerna och hans agerande som "smakdomare" är knappast unikt när det gäller forskningen om barn- och ungdomslitteratur. I min artikel "'Har du börjat ruttna i kolan?' - om värderingen av pojkdiskurs i svensk barn- och ungdomslitteratur" utgår jag från hur Vivi Edström i Barnbokens form (1980) hyllar Pippi Långstrump, som redan genom sitt namn fungerar "som en komisk uppnosighet mot ordning och principer", medan hon finner att dialogen i Bengt Linders Danteböcker "urartar till alltid lika slapp eller överenergisk jargong" (Edström 1980, 181 och 190, Öhrn 2008b, 305). Hur kommer det sig att Pippi via sin "språkliga djärvhet" går "fram som en glad tornado genom vuxenvärlden", medan Dante och Tvärsans drift med samma värld etiketteras som urartad jargong?

I Maria Nikolajevas "Det självutlämnande jaget. Den fiktiva dagboken i barn- och ungdomslitteraturen" visar sig ambivalensen via dikotomin humor-allvar: "Bert-böckerna är i sin tur alldeles för farsartade för att samtidigt erbjuda inblickar i huvudpersonens inre liv. De är öppet underhållande och fulla av halvfrivola antydningar riktade till en vuxen publik lika mycket som till de unga läsarna." (Nikolajeva 2008, 182) Även om man menar att ett av den fiktiva dagboksgenren viktigaste särdrag är gestaltningen av berättarjagets "inre liv" (ett i sig svårdefinierat särdrag), kan man fråga sig om man på sådana grunder kan avfärda en viss typ av litteratur. Förutom att de flesta barnböcker får anses vara underhållande och omfattas av idén om dubbelt tilltal, kan man undra vad "halvfrivola" syftar på i detta sammanhang - enligt $S A O B$ innebär "frivol" något "som utmärks av brist på (sedlighet) allvar 1. besinning 1. anständighet".

Bertböckerna och den tradition som är deras förutsättning, har alltså av forskningen definierats som av ringa värde, dess dialog är slapp och överenergisk och de är fulla av halvfrivola antydningar. Här finns tydliga moraliska implikationer, men sättet att reagera på kan också tolkas i termer av utanförskap. Om barnlitteratur är "en uttalat intentionell text", för att tala med Boel Westin (Westin 1998, 130), tycks pojkhumorns intention delvis vara att berätta sin grupp, 
pojkar i mellanåldern. Det rör sig såldes om en diskursiv praktik som skapar en gemenskap men som därmed också stänger ute. En viktig utgångspunkt, med tanke på det ovan sagda, är att se vad pojkhumorn gör istället för vad den inte gör, att se vad den rymmer och inte vad den saknar.

\section{Materialet - böckerna om Bert}

I föreliggande studie har jag valt att främst utgå från Berts dagbok (1987), men även göra nedslag i några av de delar som följer, samt i vissa centrala verk inom den svenska pojkhumorgenren.

Böckerna om Bert Ljung är enormt populära, bland annat har de blivit teveserie, långfilm, tecknad serie och översatts till flera olika språk. Anders Jacobssons och Sörens Olssons långserie brukar delas in i gamla och nya bokserien. Den gamla tar sin början med Berts dagbok, som bygger på en serie radioprogram från 1986, och sträcker sig fram till Berts bokslut (1999) och består av 17 böcker, inklusive en reviderad upplaga av Berts dagbok (1993). I den första boken ska Bert fylla 12 och i den avslutande är han 16 år. Den nya serien, som än så länge består av sex böcker, sträcker sig från Bert och kalla kriget (2005) till Bert och datadejten (2010). I denna svit har författarna "börjat om", det vill säga Bert är i början åter 12 år men handlingen utspelar sig nu under 2000-talet, det vill säga en anpassning till dagens mellanåldersläsare.

Samtliga böcker är skrivna i dagboksform; det rör sig om dagliga datumangivna anteckningar om 1-3 sidor och varje volym berör en tidsperiod om fyra till sex månader. Bert åldras i takt med varje ny bok till skillnad från Bill som är och förblir 11 år, det vill säga upplägget är mer realistiskt i Jacobssons och Olssons böcker. Crompton "slipper" en pubertal Bill och kan istället koncentrera sig på rackartygen. Och även om Bert delvis är att betrakta som en rackarunge, är det just hans intresse för flickor som är en av berättelsens viktigaste drivkrafter.

\section{Tjuvpojksboken och pojkhumorns rötter}

Den tradition som främst är att betrakta som Bertböckernas litterära förutsättning har många namn. Om man enbart vänder sig till Eva von Zweigbergks Barnboken i Sverige 1750-1950 (1965) ges genren namn som tjuvpojks-, odygds-, okynnes- och vildbasarboken. Hon pekar ut genrens anglosaxiska rötter och börjar med Catherine Sinclairs Holiday House (1839) som hon menar har haft stor betydelse för bland annat Cromptons Billböcker (Zweigbergk 1965, 417). Hon nämner 


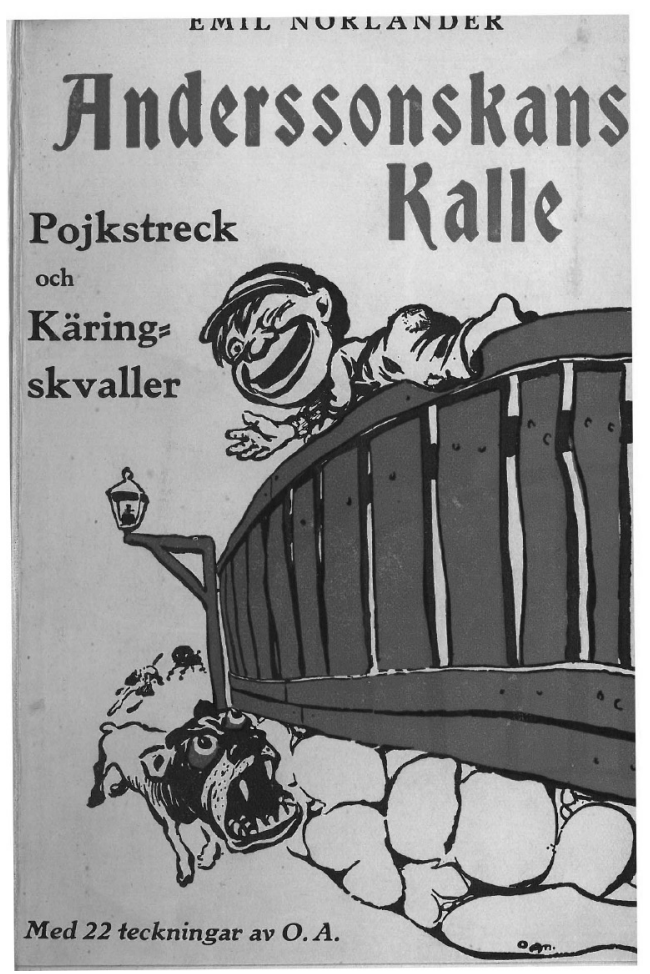

Anderssonskans Kalle av Emil Norlander, Omslagsbild av O.A. (Oskar Andersson). Ardor, 1933. (Omslaget felskuret i denna upplaga)

också Thomas Bailey Aldrichs The Story of a Bad boy (1869), som till skillnad från Sinclairs bok kom på svenska och fick titeln En stygg pojkes historia (1880). I sin artikel "Tjuvpojksboken" menar Lennart Hellsing att Metta Victoria Fuller Victors The Bad Boy's Diary (1880), på svenska En liten ostyrings Dagbok (1883), har haft stort inflytande på genren, inte minst för att den är skriven ur huvudpersonens perspektiv, med stavfel och allt (Hellsing 1972, 36). "Litterärt sett", skriver Hellsing, "har genren sina rötter hos de stora amerikanska humoristerna Washington Irving och Mark Twain", han pekar även ut Booth Tarkingtons Penrod (1914) som kom i svensk översättning 1918 (40). Zweigbergk understryker också Twains betydelse (Zweigbergk 1965, 419).

Hon menar vidare att Topelius "gav oss den första vildbasaren, den första odygdspåsen i svensk litteratur" (120), men att Emil Norlander skrev "den första svenska tjuvpojksboken" i och med Anderssonskans Kalle (1901). Även Hellsing antyder det inflytande som Topelius haft på den svenska traditionen i det han nämner "Bullerbasius", men vill inte räkna den till genren, "därför att Bullerbasius tvingas ångra sig och bli en snäll gosse." (Hellsing 1972, 40) Han är också tveksam till om Norlanders bok bör sorteras som tjuvpojksbok: "Kanske hör södervarianten Anderssonskans Kalle också dit." Denna tveksamhet drabbar även andra svenska verk som brukar räknas till genren: "Någon renodlad tjuvpojksbok av svenskt ursprung känner jag inte till, däremot är Emil i Lönneberga en småländsk bondevariant. Sigge Strömbergs böcker, som ju kallas tjuvpojksböcker, är däremot mer av samma typ som Tom Sawyer och Huckleberry Finn, dvs. äventyrsböcker med inslag av odygder." (40)

Den ambivalens som genomsyrar Hellsings artikel tycks bottna just i dikotomierna humor-allvar och seriös kontra populär litteratur; den underförstådda frågan är: kan han som vuxen rättfärdiga sin barndomsläsning av Bill? Hans strategi blir att söka ge Bill en historia, 
en litterär bakgrund. Detta var med svenska ögon ett oprövat projekt, i vilket han prövar sig fram i syfte att definiera genren.

Hellsings centrala begrepp nämns redan i artikelns titel: "Tjuvpojksboken" och även om det är vedertaget är det dubbelt problematiskt. För det första antyder tjuvpojke, i likhet med de övriga benämningarna som nämndes ovan, att pojkfigurerna i de aktuella texterna utgör en avvikelse från vad som är accepterat, pojken som ett moraliskt problem: en tjuv som bör straffas. För det andra är tjuvpojke ett historiskt tyngt begrepp, som bär med sig konnotationer från 1600-talet och framåt (SAOB:s tidigaste svenska belägg är 1690). Det tvehövdat problematiska ligger i att Bill är en avläggare till en ny pojktyp i litteraturen (och i andra genrer), eller rättare ett nytt sätt att förhålla sig till pojkdomens normbrytande, som just innebar att pojken inte i första hand skulle straffas.

\section{Pojkologin och den milde vilden}

Den förändrade inställningen till pojkars vildhet som börjar märkas i slutet av 1800-talet har varit föremål för en rad amerikanska studier, varav den mest betydelsefulla är Kenneth B. Kidds Making American Boys (2004). Kidd hävdar att en av de diskurser som format det ideologiska och praktiska arbetet med pojkar i USA är den som brukar benämnas boyology (Kidd 2004, 1). Med pojkologi avses ett både deskriptivt och normativt skrivande om pojkdom i flera olika genrer och det är en diskurs som Kidd spårar fram till vår egen tid. Begreppet manifesterades via YMCA-ledaren Henry William Gibsons bok Boyology or Boy Analysis (1916), en rådgivningsbok som sammanställer det hundratalet böcker som hade kommit ut i USA sedan William Byron Forbush The Boy Problem (1901).

Pojkologin beskrivs av Kidd som ett kluster av idéer med vissa gemensamma drag, vilka i korthet går ut på en positiv grundsyn på de vilda pojkåren, då de utgör en övergående fas som är att jämföra med tidiga skeden i mänsklighetens utveckling. Denna fas sågs som en nödvändig del av pojkens utveckling till man (Kidd 2004, 57). Rådgivningslitteraturen handlade mindre om att straffa och mer om att vägleda pojkarna, vädja till deras förnuft, man talar om the gentle savage (55).

Kidd menar att det mesta av detta tankegods var hämtat från det som brukar benämnas the American boy book, det vill säga den självbiografiska genre där nordamerikanska män mindes sin pojkdom och som tidsmässigt ringas in av amerikanska inbördeskriget och 
första världskriget. Precis som Marcia Jacobson konstaterar i Being a Boy Again. Autobiography and the American Boy Book (1994) rör det sig om en genre där Twain utgör ett kanoniserat epicentrum. När Zweigbergk och Hellsing pekar ut Aldrich, Tarkington och Twain som litterära förutsättningar till den svenska tjuvpojksboken, handlar det i själva verket om en genre med en rad gemensamma drag, varav det intressantaste i detta sammanhang är den sammansatta bilden av pojken som en mild vilde, eller som Aldrich uttrycker det i den svenska översättningen, en "temligen stygg" pojke (Aldrich $1880,1)$.

\section{Pojkologins tre faser}

Kenneth B. Kidd ser pojkologins utveckling i tre faser, först den litterära som består just i the American boy book. Därefter den institutionaliserade, det vill säga den stora mängd rådgivningsböcker som kom i början av 1900-talet och som ofta skrevs av män som arbetade inom olika organisationer som riktade sig till pojkar, såsom YMCA och scouterna. Slutligen den fas Kidd ser idag, som han kallar den psykologiska; han syftar på de samtida populärvetenskapliga böcker som ger föräldrar råd i hur de ska förhålla sig till sina söner (18).

Även om den pojkologiska diskursen hittar till vår del av världen är det svårt att se den typ av tydliga faser, vare sig kronologiskt eller genremässigt (men här saknas forskning). Visserligen fanns i vårt land, som Ulf Boëthius visat och diskuterat i När Nick Carter drevs på flykten (1989), en rörelse och en debatt angående ungdomens förvildning kring förra sekelskiftet. Men det rör sig knappast om hur man ska gå till väga för att domestisera medelklassungdomar, som i USA, utan mer vilka åtgärder man från statligt håll bör rikta mot arbetarklassungdomens sedeslöshet (Boëthius 1989, 234). Man kan dock hitta några exempel på det Kidd kallar för den institutionaliserade pojkologin, såsom i Sven Lundqvists Uppfostran under skolåldern (1901). Under rubriken "Hyfsning" möter vi bilden av pojken som vilde: "Barnet innehar vid sin födelse en utvecklingsmöjlighet, som nästan lättare leder till vilde än till civiliserad människa. Lämna det åt sig själft, och det växer upp till vilde [...] till ett lif i otyglat begär. Vaka öfver det, att dessa hållas inom måttlighetens gränser, och barnet blir en hyfsad hjälte. Vildar kunna vara i besittning af stor själfbehärskningsförmåga." (Lundqvist 1901, 316) Som synes finns här pojkologins idé om något gott hos vilden och att det inte handlar om att göra om pojken utan mer att vaka över att begären hålls inom vissa gränser. 
Ett snarlikt resonemang hittar man i den tyske pedagogen Adolf Matthias Huru vi skola uppfostra våra söner (1914), som förutom svenska översattes till en mängd språk, bland annat japanska, något som indirekt visar på pojkologins idé om en universell pojke. Matthias kallar det "slyngel- eller lymmelåren", under vilka gossen är en "riktig flabb" och "ser ut som en åsna" (Matthias 1914, 131). Lymmelns uppförande drar åt det djuriska, det präglas av "outsäglig råhet, ostädat skick, obändighet, tygellöshet i hela väsendet framträda och yttra sig i planlagd våldsamhet, retsamhet och rått plågande av yngre barn, $\mathrm{i}$ hånande av gamla, bräckliga personer" (132). Men så händer något, slyngelåren har även sina goda sidor, det är bland annat nu som "gossen visar stark hänförelse för fosterland, frihet och manlig värdighet." (133) Här har vi återigen den godhjärtade vilden och följaktligen handlar det inte om att aga, kränka eller förbjuda pojken, utan om helt andra tillvägagångssätt; Matthias sammanfattar: "Att kunna hava överseende, men likväl se efter, må vara lösen för behandlingen av slynglar." (136) Matthias avslutar med att understryka att slyngelåren är en övergående, men för manligblivandet, nödvändig fas.

\section{Svensk pojkologi}

Någon direkt motsvarighet till genren the American boy book har vi inte i svensk litteraturhistoria, åtminstone inte vad gäller tidsperioden och författarnas nätverk. Väljer man att bortse från detta och koncentrerar sig på realistiska pojkdomsskildringar skulle en svensk gren kunna bestå av Sigfrid Siwertz Mälarpirater (1911) och Bombi Bitt och jag (1932). De har självbiografiska inslag, riktade till en vuxen publik som blivit populär pojkläsning och haft ett visst inflytande på vår bild av pojken och huvudpersonerna är "temligen stygga", för att travestera Aldrichs. Båda dessa, i synnerhet den senare, vilar också tungt mot den amerikanska genren och Twain.

Det går dock att hitta ett par tidiga exempel på en mer sammansatt pojkgestalt i svensk barn- och ungdomslitteratur. En sådan är Gösta i Hugo Falks Gösta Svärdfält och båtsman Våghals. (1898). Upptakten i denna äventyrsbok utgörs av en realistisk skildring av en läroverksgosses våndor inför latinläxan. Efter att vi fått veta att Gösta ägnar mer tid åt lekar än åt pluggande, finner berättaren det påkallat att försvara honom: "Man är inte ung mer än en gång. Jag är nog omoralisk att tycka, att han gjorde rätt - trots alla lillgamla bleknosar, som sätta mera värde på en prydlig latinsk sentens än på en lyra" (Falk 1898, 35). 
Den mest ihärdiga och förmodligen viktigaste introduktören av pojkologins sammansatta pojke i Sverige var Ebbe Lieberath. Som officer, gymnastiklärare, ordförande i Svenska scoutförbundet och författare representerade Lieberath både de litterära och institutionella idéerna, även om de senare hade stor inverkan på hans pojkböcker. Hans allt annat än dolda agenda har tidigare påpekats i en artikel av Ylva Blomqvist: "Lieberaths fostrande projekt kan spåras i vad som liknar en medveten lansering av ett ideal. Ett ideal som tar form i den klämmiga pojkens gestalt." (Blomqvist 1999, 24)

De klämmiga pojkarna skulle sedan följa honom författarskapet ut, men var vid tiden en nyhet och torde i vissa läger ha stött på patrull. I inledningen av Gränsridare (1917) ser han sig föranledd att lägga ut texten efter att ha presenterat historiens fyra huvudpersoner:

Men jag menar, att en "pojke av renaste vatten", som man säger, behöver inte vara precis den lilla ängel, som dessa orden tytt på. Tvärt om anser jag att ett litet stänk av tjuvpojke är ett avsevärt plus hos honom, ty då är han åtminstone inte en mes eller morsgris utan en pigg och vaken fyr, som vet att komma ned på fötterna som en katt, hur än ödet hyvar honom.

Den där sortens pojkar, som tar emot en orre utan att ge igen, som ryser i sitt innersta, när han ser en kamrat snyta blod efter en batalj och som tar till benen så snart det börjar se dystert ut för laget - nej, låt oss tala tyst om en sådan. (Lieberath 1917, 9f)

Utläggningen påminner om Falks men Lieberaths är mer rättfram och programmatisk, ett svenskt exempel på den pojkologiska diskursen. Men även om de klämmiga pojkar han introducerade spelar en viktig roll för svensk pojkhumor, är det hans böcker från 1920-talets mitt och framåt som får räknas in i en svensk litterär pojkhumortradition. I böcker som Klämmiga pojkar (1924) och Julle, Långstroppen och vi (1925) finns en tydlig jagberättare i mellanåldern som är väl förtrogen med den aktuella pojkdiskursen, såsom slang, ordvitsar och språkliga missuppfattningar (se Öhrn 2008b, 307f).

\section{Den första svenska tjuvpojksboken}

Som vi sett ovan menar Eva von Zweigbergk att Andersonsskans Kalle är den första svenska tjuvpojksboken, men frågan är vad den har haft för reellt inflytande på den svenska pojkhumorn. Han är knappast en godhjärtad tjuvpojke. Vi får aldrig veta vad han tänker eller 
känner, han utvecklas aldrig, snarast är han en funktion. Möjligen kan man se honom som en våldsam motreaktion mot 1800-talets didaktiska barnlitteraturs mesar, morsgrisar och blekfisar, för att tala med Falk och Lieberath, samtidigt som han i likhet med den tidiga barnlitteraturens olydiga gossar bestraffas, dock utan att bättra sig. En annan ingång är att se Norlanders text som ett exempel på det Kenneth B. Kidd kallar feral (vild) tale, som han menar är den diskurs vid sidan om pokjologin som mest påverkat synen på pojkar i USA. Denna "vilda saga" menar Kidd är ett europeiskt fenomen som utvecklats ur olika typer av folklore och som dramatiserar pojkars vildhet (Kidd 2004, 1). Det vanligaste exemplet på denna pojktyp är Kiplings Mowgli, som fostras av vargar; intressant är att Anderssonskans Kalle vid flera tillfällen benämns just vargunge (Kidd betraktar just Baden-Powells scouter/vargungar som en fusion av den vilda pojksaga som Kipling representerar och pojkologins mer domesticerande diskurs, s. 7)

Så är då Anderssonskans Kalle en tjuvpojksbok? Med tanke på ovanstående diskussion om det problematiska med ett begrepp som inte riktigt täcker in pojkologins förändrade förhållningssätt till pojkens vildhet, ska kanske Norlanders verk räknas som en tjuvpojksbok i ordets "rätta" bemärkelse. En figur som ständigt bryter mot regler och normer och som, likt en tjuv, straffas härför. Ytterligare ett problem är att man vid denna tid använde begreppet om snart sagt alla pojkfigurer som agerade normbrytande, även de godhjärtade. Det är dock viktigt att påpeka att det hos exempelvis Lieberath finns ansatser till att nyansera begreppet, som i citatet ovan när han talar om ett "stänk av tjuvpojke". Och även om Strömbergs hjältar benämns tjuvpojkar rör det sig dels om långt mer sammansatta gestalter än Anderssonskans Kalle, vilka själva får komma till tals, dels om en vuxenvärld som accepterar vissa av "hyssen".

\section{En svensk pojkhumortradition}

Även om Hellsings genredefinition av tjuvpojksboken är att betrakta som ett försök, där genredragen "renodlats" ur böckerna om Bill, utgör den en fruktbar utgångspunkt när man vill diskutera svensk litterär pojkhumor. Nedan ett försök till definition med hjälp av Hellsings beskrivning av tjuvpojksboken (citat från Hellsing i parentes, 39):

- Episodisk ("en serie kortare humoristiska berättelser")

- Huvudpersonen är en pojke eller flera pojkar i mellanåldern ("en 
pojke på omkring elva år är genomgående centralfigur" och som umgås med "pojkvänner")

- Hjälten har flickvän eller förhåller sig på annat sätt till den heteronormativa matrisen ("en mer eller mindre genomgående 'flamma'"')

- Hjälten bryter mot regler, lagar och normer ("pojkstreck")

- Utspelar sig i hemmet, skolan och pojklandet ("utspelar sig i hemmet eller dess närmaste omgivningar", "skolan skymtar")

- Berättas ur hjältens perspektiv, ofta i första person och på pojkarnas eget språk ("författaren tar helt och hållet parti för hjälten")

- Förlöjligar på olika sätt vuxenvärlden ("samhällskritiska och satiriska")

Det Hellsing inte direkt diskuterar är i vilken utsträckning vuxenvärlden accepterar pojkarnas beteende, vilket kan bero på antagandet att en sådan tillåtande sida inte existerar i en genre som bryter mot och förlöjligar den samma. Det ena utesluter dock inte det andra, i synnerhet fäderna spelar här en dubbel roll, exempelvis i Strömbergs böcker (se även diskussionen om pappans dubbla agenda i Gustaf af Geijerstams Mina pojkar (1896) i Öhrn 2010, 193).

Även om nu Anderssonskans Kalle uppfyller vissa kriterier, såsom den episodiska strukturen och normbrotten, saknas andra väsentliga drag. I Norlanders bok är det dessutom en av gårdens kvinnor som för ordet, något som Conny Svensson tydligt visar i sin läsning av boken i Tarzan i slukaråldern (1997): "Inga lustiga repliker kommer ur Kalles mun, för det språkliga överdådet svarar istället Pilgrenskan då hon i efterhand relaterar buspojkens bravader." (Svensson 1997, 94f) Kalle kan heller inte räknas till mellanåldern, han introduceras i historien genom att suga på tummen.

En god startpunkt för den svenska pojkhumorn är istället just Strömbergs böcker om de två tjuvpojkarna Kalle och Ville, inalles sex stycken som gavs ut mellan åren 1915 och 1920. Ett annat tidigt exempel är Erik Zetterströms Två år i varje klass (1923), som Zweigbergk menar är "en mycket läsbar odygdsbok" (422), och naturligtvis uppföljaren Sigge Nilsson och jag (1926). Precis som i Strömbergs böcker är det en pojke som berättar och den aversion mot skolan som är en viktig del av pojkkonstruktionen hos Strömberg (och i en lång rad pojkböcker) blir det bärande temat hos Zetterström.

Till genren bör också Bengt Linders långserieböcker om Dante räknas, vilka tog sin start med Dante, toppsmart kille 1966 och avslutades 25 böcker senare med Smack $i$ smöret, Dante (1980). En invändning man kan ha är att det inte är Dante själv som för ordet, men 
dels inleds varje bok med ett förord signerat huvudpersonen och dels är den allvetande berättarens framställning förvillande lik Dantes idiom. Dessutom skriver böckerna in sig i genren intertextuellt, som i Tvärsans uttalande i Kolla skägget, Dante! (1968): "En del föräldrar har ju ett brokigt förflutet. Ibland vill dom ju inte ens visa upp sina betyg från plugget. Ibland misstänker jag att min gubbe gick två år i varje klass." (Linder 1968, 8)

På samma sätt som Linders text går i dialog med Zetterströms, finns det $\mathrm{i}$ barn- och ungdomslitteraturens minne intertexter som visar på föregångare. I Mats Berggrens Kalsonger med gröna älgar (1991) är det just Dante och hans jargong som pekas ut: "Munduellernas mästare. Ordak-

\section{B.WAHLSTRÖMS UNGDOMSBÖCKER}

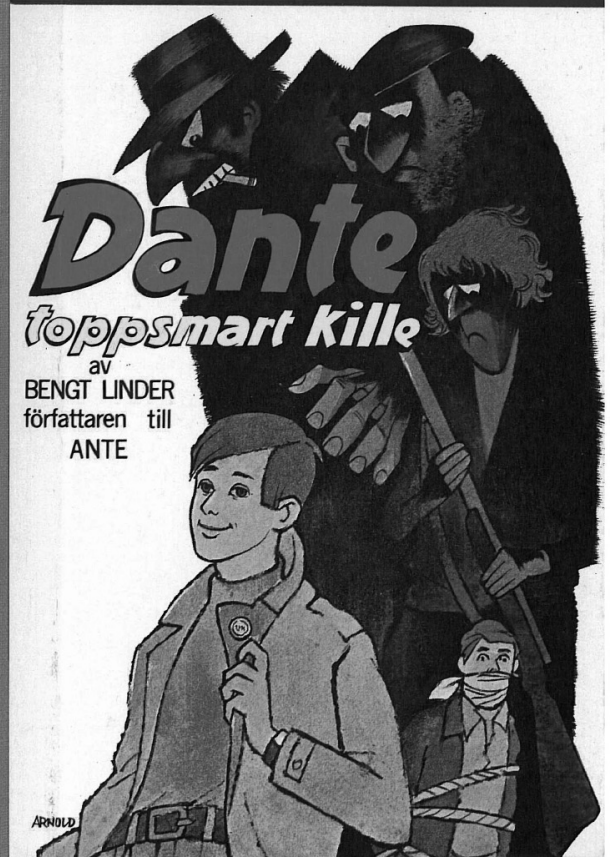

(C) Dante, toppsmart kille av Bengt Linder. Omslagsbild av Hans Arnold, B.Wahlström, 1966. robatiken som lurade ut tjogvis med vuxna på muntlig slalom för att slänga av dem i närmsta stup. [...] Efter Dantes och hans vapendragare Tvärsans höga föredöme bildade vi Matsarnas Secret Club." (Berggren 1991, 10)

Här tycks således finnas ett gap mellan 1920-talet och fram till att Dante dök upp vid 1960-talets mitt när det gäller svenskproducerad pojkhumor. Detta glapp torde bero på att Billböckerna dominerade genren om man ser till vad svenska pojkar i mellanåldern läste under denna tid (Larson 1947, 22). Vidare kan man konstatera att både Strömbergs och Zetterströms böcker kom i nyutgåvor under denna period, Strömbergs så sent som 1955-59. Men glappet kan också förklaras med en lucka i forskningen, det existerar i nuläget ingen undersökning om svensk litterär pojkhumor från denna tid.

\section{Svensk pojkhumor mellan 1920-talet och Bertböckerna}

I väntan på en sådan studie vill jag här nämna några titlar som till vissa väsentliga delar skulle kunna sorteras som pojkhumor. Till dessa hör ett par av Dan Byströms böcker, såsom De tios förbund (1926) och 
Julles sanna berättelser ur livet (1936), den senare en episodisk redogörelse för diverse hyss, emellanåt förmedlade i dagboksform. Precis som hos Strömberg vänder Byström då och då på perspektivet och skyller pojkarnas hyss på vuxenvärlden: "Det finns nämligen alltid folk, som gör rackartyg för pojkar och sen skyller dom på oss sedan, och det är väl inte rättvist." (Byström 1936, 44) Möjligen ska Anders Ejes tre böcker om John och Jerry, som kom ut mellan 1934 och 1938, räknas hit. De utspelar sig visserligen på olika exotiska platser, men bygger mycket på jargongen pojkarna emellan och har vissa groteska inslag. Slutligen Bengt Westergrens tre böcker om Harry A:son utgivna mellan 1952-55, som närmast är att betrakta som äventyrsböcker, men som inleds och avslutas med längre partier i hem- och skolmiljö. De präglas av ett direkt tilltal till en tydligt tänkt läsare, som i första boken Harry A:son, upptäcktsresande (1952): "Mors, grabbar! Det är Harry A:son som talar." (Westergren 1952, 3) De behärskas således av en pojkdiskurs som är gemensamhetsskapande, men som också exkluderar, som när Harry, Kluten och Berra stänger ute Pluggen, den förhatliga plugghästen i Harry A:son, tigerjägare (1955): "Han försöker bli buss med oss och slinka med i snacket på något sätt men när han märker, att inge tar notis om'en, blir han lite stucken och avig och börjar rätt vad det är ge mej gliringar." (Westergren $1955,10)$

De nämnda texterna (och förmodligen ytterligare några till) kan sägas utgöra en svensk variant av litterär pojkhumor som i långa stycken stämmer in med Lennart Hellsings definition av tjuvpojksboken. Det är till denna tradition som jag vill räkna in böckerna om Bert.

\section{Exemplet Bert}

\section{Pojkhumorn i böckerna om Bert}

Förutsättningarna för skrattet i den ovan skissade traditionen och i Berts dagböcker griper över flera av de genredrag som Hellsing tillskriver tjuvpojksboken, framför allt "pojkstrecken" (regelbrytandet) och de "samhällskritiska och satiriska" utgångspunkterna. Det handlar således om en detroniserande strategi som riktar sig främst mot vuxenvärlden, ett normbrytande och förlöjligande som accentueras av att det förmedlas ur pojkarnas perspektiv, via en pojkhumordiskurs som präglas av ordlekar och vilar på en groteskt realistisk världsbild. Nedan önskar jag därför peka ut och diskutera dessa drag i böckerna om Bert. 


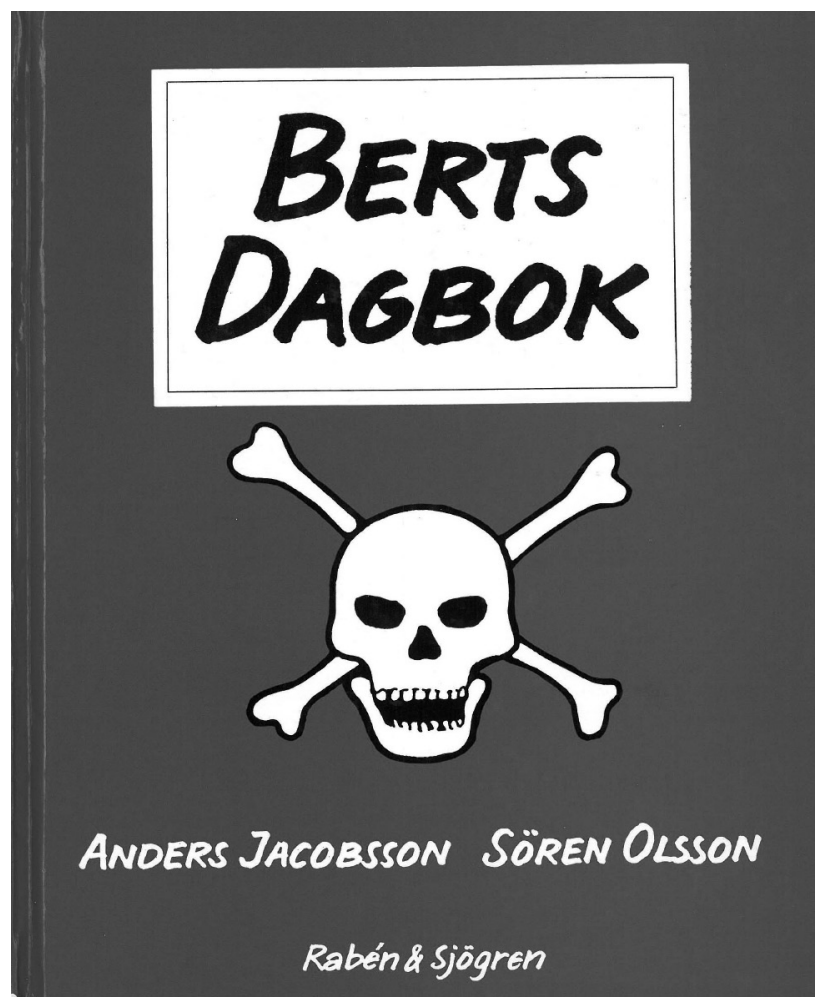

(C) Berts dagbok av Anders Jacobsson och Sören Olsson. Omslagsbild av Catarina och Petter Magnusson. Rabén \& Sjögren, 1987.

\section{Det karnevalska}

Berts dagbok inleds med vad som kan liknas vid en karnevalisk programförklaring. Bert ritar en dödskalle på framsidan i syfte att maskulinisera en traditionellt kvinnlig genre, dagboken. Men detta var inte hans ursprungliga idé: "Först tänkte jag rita en hjärna i stället för ett hjärta. Men det såg ut som sex korvar som låg på varandra." (Jacobsson 1987,11) Tanken på att byta ut hjärtat (känslan) mot hjärnan (förnuftet) aktualiserar ett motsatspar som historiskt sett använts för att beskriva skillnaderna mellan könen. Men istället för en hjärna blir det korvar, "högt" blir "lågt" via en maträtt som närmast är att betrakta som en symbol för den karnevaliska världsbilden. En produkt bestående av olika typer av djurdelar instoppade i en tarm kan ses som en komprimerad bild av det muntra kretslopp där död ger liv. En sådan munter förvandling serveras redan den första dagen i den sång som killarna i Berts klass har hittat på för att reta de tjejer som gillar hästar, i synnerhet King: "King är jätteding/Plingelingelingeling/Snart är King ingenting/Bara en falukorvsring" (15). 
Korven genomsyrar texten på flera olika nivåer. För det första äts det mycket korv, som under klassens skidutflykt, där man får följa korven en bit på sin väg genom det muntra kretsloppet, in i munnen: "Näha, sa Jesper mellan korvtuggorna." (27) Korven blir här också föremål för frosseri: "Klimpen satt och skröt med hur många korvar han ätit." (27) Den utnyttjas också i bildspråk, som när Bert får en balettrikå i födelsedagspresent: "Jag såg ut som en korv." (49) Såsom karnevalisk symbolär den också att uppfatta som komisk, vilketbland annat märks i hur den används i de rim och ordvitsar som är en viktig del av pojkdiskursen, såsom i en av de inledande hälsningsfraserna till dagboken: "Hej, dagboken. Tjo faderalla, prinskorv åt alla." (101) Den blir också föremål för komiska omskrivningar, som när korv med bröd döps om till rulle med handplätt (41). Samtidigt är korven ofta synonym med mat, på samma sätt som sagans pannkaka. Detta blir tydligt när pappan försöker fasta: "Pappa håller på att dö. Jag retade honom. - Ska du ha en korv, farsan?" (70)

Just faderns misslyckade försök att fasta kan ses som något av en karnevalisk situation. Bert hittar brödsmulor på toaletten: "Farsan smygäter på WC, viskade jag till mamma." (70) Karnevalen innebar ursprungligen ett farväl till köttet just innan fasteperioden. Berts pappa klarar dock inte av denna avhållsamhet och bilden av honom intagande mat på det ställe där man ska avbörda sig den blir, i likhet med korven han erbjuds av sin son, en bild över det muntra kretsloppet. Värt att notera är att fadern försöker fasta vid påsk, den tidpunkt då fastetiden enligt den äldre katolska traditionen var över.

\section{Grotesken}

$\mathrm{Nu}$ är inte Berts dagbok att räkna som en karnevalisk text, snarare handlar det om att den behärskas av den estetiska tradition som Bachtin menar växt fram ur den folkliga karnevalskulturen och som han kallar grotesk realism. Dagboken genomsyras av ett groteskt modus och i centrum för detta sätt att beskriva världen står kroppen och de olika akterna i det kroppsliga dramat. I "The Masculine Mode" menar Peter Schwenger att det litterära utforskandet av manlighet ofta handlar om uttalat kroppsliga erfarenheter och att dessa förmedlas just via ett groteskt modus (Schwenger 1989).

Historiskt sett är det groteskt kroppsliga utforskandet av manskroppen något som främst återfinns i vuxenlitteraturen, men vi finner spår av det i barn- och ungdomslitteraturen, i synnerhet inom pojkhumorn och framför allt i bildspråket. I Westergrens Harry A:son, upptäcktsresande hittar man följande beskrivning av en illvillig lärare: "Sen halar han fram en liten anteckningsbok ur fickan och skriver in nånting, medan tungspetsen hela tiden slingrar sej som en 
metmask ut och in mellan läpparna." (Westergren 1952, 8) Sammanblandningen mellan människa och djur för tankarna till de murala utsmyckningar från antikens Rom som givit upphov till begreppet grotesk.

I böckerna om Dante är det groteska moduset något mer utvecklat. Även här finner man det i bildspråket, som i Vicken panggrej, Dante: "denna skakande upplevelse som fick blindtarmen att hoppa ur sitt fodral" (Linder 1974, 39). Här närmar man sig en av den groteska kroppens viktigasteområden, magen, meni Linders böckerhittar man även fler exempel på en annan väsentlig kroppsdel i sammanhanget: "Tvärsan klatschade till Dantes gumma i baken så att hon hoppade ur tofflorna" (43). I Berts dagbok är denna del av kroppen inskriven i huvudpersonens namn: "Det rimmar på en viss del av kroppen." (Jacobsson 1987, 11)

Om den groteska realismen länge har varit en viktig del av den muntliga pojkdiskursen, är det först på senare år som den på allvar har hittat in i barnlitteraturen. Ett exempel på denna trafik hittar man i Hans Erik Engqvists Rymmarna (1978): "En rapning, det är en ifrån magen kommande, genom matstrupen vibrerande, över tungan farande brakskit, som förkunnar att röven gått i baklås. Amen." (Engqvist 1978, 17). ${ }^{1}$ Bert, med sina explicit redovisade kroppsliga erfarenheter av pojkdomen, kan måhända ses som en föregångare vilket delvis skulle kunna förklara böckernas popularitet.

Det groteska moduset i Bertböckerna tar sig också uttryck i utforskandet av en kropp i förvandling, det Bachtin kallar den gränslösa kroppen (Bachtin 1986, 309ff). I Berts fall om förvandlingen från pojke till man. Det handlar om allt från tillfälliga kroppsliga förändringar, "Jag har fått en fläskläpp" (Jacobsson 1987, 47), till mer långvariga: "Jag tror jag börjar få horn. Det har vuxit någonting i pannan som är rött och gör ont. - Det är bara en vanlig finne, säger mamma." (44) Här exemplifieras både hyperbolen (acne blir till horn) och den gränslösa kroppen (saker växer ut ur pannan).

Ett annat sätta att gestalta kroppens groteska liv och dess förbindelse med omvärlden är via olika typer av kroppsavsöndringar (Bachtin 1986, 314). Pojkkropparna i Berts dagbok blöder, pussas, hostar, kräks, svettas och nyser; det sistnämnda händer när Bo-Göran dansar tryckare med Yvonne: "Då nös han. Yvonne blev kladdig i hela ansiktet." (Jacobsson 1987, 56) En annan viktig akt i det kroppsliga dramat som bereds stort utrymme i Berts dagbok är sjukdomar. Dessa personifieras via en hyperboliskt uppfattad varelse: "En bautabacill! Stor som ett mjölkpaket. Bautabacillen är grön och har fjorton ögon. Sjukdomar som man får av bautabacillen: maginfluensa/ vattenkoppar/pesten/närsynthet." (62) Denna uppräkning kan i 
sin tur ses som ett exempel på det Bachtin benämner räckor, som ofta utgör långa listor på mat och dryck (Bachtin 1986, 185). I Berts dagbok söker huvudpersonen organisera sitt vetande just via en mängd uppräkningar, inte minst av mat och dryck. Men det handlar då främst om sådant man inte vill inta: "Det finns ganska mycket mat som inte går att äta. Kräkmat. Jag har gjort en kräklista för otillåtna maträtter. Här är den: blodpudding/pölsa/sylta/svamp/gröt/Åkes pappas kåldolmar." (Jacobsson 1987, 46)

Som Anna Lundberg påpekar i sin avhandling Allt annat än allvar. Den komiska kvinnliga grotesken i svensk samtida skrattkultur (2008) är den skrattkultur som Bachtin diskuterar "företrädesvis manligt konnoterad och mycket heteronormativ." (Lundberg 2008, 18) Lundberg fortsätter: "Ur ett feministiskt perspektiv är detta inte särskilt förvånansvärt eftersom kvinnlighet och groteskeri har en lång tradition av att uppfattas som varandras diametrala motsats: att bete sig kvinnligt framstår som en antites till att bete sig groteskt." (18) Ett utmärkande exempel på detta är när Bert får en röd gummiorm av Rebecka i födelsepresent. Klimpen ser genast gåvans falliska potential: "Klimpen frågade Rebecka ifall inte min vanliga pillesnorre dög, eftersom hon köpt en av gummi. - Äckliga snuskäckel, sa Rebecka." (Jacobsson 1987, 52)

\section{Detronisering}

I Jacobssons och Olssons texter hittar man exempel på klassiska karnevaliska detroniseringar, som av kyrkan: "Prästen med gesten/tappade byxan på festen" (21). Med tanke på att vi lever i ett av världens mest sekulariserade länder ter sig det återkommande förlöjligandet av kyrkan i Berts dagböcker som något otidsenlig. Men det skulle kunna förklaras med att de båda författarna, som är födda i början av 1960-talet, skolades in i diskursen när kyrkan fortfarande hade ett visst inflytande och därmed också blev föremål för förlöjliganden. Detta något föråldrade inslag har sin motsvarighet i den manliga förebild som förekommer flitigast i bokserien, nämligen Fantomen. Intressant $\mathrm{i}$ sammanhanget är att den vandrande vålnaden vid ett par tillfällen ställs mot just en representant för den sakrosanta sfären, som när Bert läser högt ur Bibeln för sin mormor: "Jag ändrade lite på berättelsen. Jag sa Fantomen istället för Jesus." (71) Frågan är här vilken av de båda storheterna det är som upphöjs respektive detroniseras? Vänder man sig till den första boken i den nya serien, Bert och kalla kriget, finns en utläggning som talar till Fantomens fördel: "Fantomen är ungefär som Jesus. Fast med en fördel: Fantomen får slå onda på käften om de beter sig illa. Jesus ska bara vara snäll och vända andra kinden till." (Jacobsson 2005, 10) 
Men den mest genomförda detroniseringen i böckerna om Bert drabbar hans pappa. Kortfattat har fadern i barn- och ungdomslitteraturen gått från att under 1800-talet ha varit en närvarande auktoritet till att under 1900-talet mer och mer försvinna ur fokus, en utveckling som Marika Andræ noterar i Rött eller grönt? Flicka blir kvinna och pojke blir man i B. Wahlströms ungdomsböcker 1914-1944 (2001): "Likgiltigheten inför vuxna män är ingen ovanlig hållning i pojkarnas autonoma värld [...] De vardagliga männen spelar en underordnad roll som förebilder." (Andræ 2001, 172) Det som kännetecknar fäderna i de tidiga exemplen på pojkhumor, som hos Strömbergs fem böcker om de två tjuvpojkarna och Zetterströms Två år i varje klass, är deras frånvaro, eller som det heter när Sigge Nilsson får underbetyg: "Morsan grina å farsan va inte hemma." (Zetterström 1923, 103) När fäderna emellanåt griper in i handlingen, såsom i Strömbergs böcker, sker det ofta på ett ickeauktoritärt sätt, pappan upplevs som "urbussig".

I detta perspektiv visar böckerna om Bert på ytterligare en vändning. Pappan är inte längre den undflyende och frånvarande figur som sonen söker förstå, såsom i Ulf Starks böcker (se Öhrn 2008a, 143). I Berts värld har pappan åter trätt in på scenen, $i$ hemmet, men han är långt ifrån den auktoritära förebild han en gång var, inte heller upplevs han som bussig. Han är mer att betrakta som en variant av den töntige och tafatte svenska mannen som har sin givna plast $i$ svensk humortradition (såsom Lasse Åbergs Stig-Helmer och Gösta Ekmans Papphammar). Detroniseringen av honom påbörjas redan i inledningen av Berts dagbok: "Min farsa har en Opel som tutar när man svänger. Han heter Fredrik. Alltså inte Opeln utan min farsa." (Jacobsson 1987, 13f) Förlöjligandet tar sig här uttryck i pappans okunnighet om maskiner. Pappans låga status utnyttjas också för att förlöjliga Berts hjälte, som när olika Fantomen-ordspråk parodieras i: "När Fantomen är pappa är han larvig." (60)

Om neddragningarna av fadern delvis förstås mellan raderna i Berts dagbok, skrivs de ut tydligare och förklaras vartefter serien framskrider, så att det inte ska råda något tvivel om att pappan i det här hänseendet inte är någon förebild. Ett exempel finns i Berts bekännelser (1992) när pappan åker moped: "Den åderförkalkade gamle gubbkraken glömde bort på vilken sida handbromsen satt." (Jacobsson 1992, 37) Här understryks åldersskillnaden, pappan är för gammal för att vara en förebild. I Danteböckerna är detta avstånd permanentat via benämningarna "gubben" och "gumman" för pappan och mamman. Fadern går såldes från att vara en komisk gestalt till att uppfattas som mer tragikomisk. Blickar man framåt mot den nya seriens första del, Bert och kalla kriget, tycks denna 
utveckling vara något som även dagboksförfattaren funderar kring: Mamma "säger att jag fått min humor efter far. Det kan vara så. För om jag har fått den av honom så förklarar det varför han aldrig är rolig längre, bara tragisk." (Jacobsson 2005, 43)

\section{Språkleken}

Pojkhumorn i Bertböckerna behärskas av ett språklekande modus, som tar sig uttryck i olika typer av vitsande och rim. Språkleken är i sin tur ofta sammanlänkat med det groteska, som i Berts sång om sina kusiner: "Malin och Desiré, de har diarré." (Jacobsson $1987,72)$ Och precis som den groteska realismen har även vitsandet kommit att betraktats som manligt kodad. I artikeln "The Fraternal Bond as a Joking Relationship" pekar Peter Lyman ut vitsen som en bekräftande aktivitet inom mansgruppen: förstår man vitsen tillhör man gemenskapen (Lyman 1987).

Rimmandet i texten kan tyckas naivt och föga betydelsebärande, som det nonsensartade "Tjing, tjong. Pling, plong dagboken" (Jacobsson 1987, 94) eller namnrim som "Rut har en stor trut", med förklaringen: "Men så värst stor är den inte." (19) Det sistnämnda exemplet visar dock på rimmets makt då Rut, trots att hon inte har en stor mun, därefter benämns "Rut med sin trut". Denna rimmets logik drabbar också Bert, vars namn, som påpekats ovan, "rimmar på en viss del av kroppen. Den delen man sitter på." (11) De kanske mest betydelsebärande rimmen är de som upprepas vid slutet av varje dags noteringar, i Berts dagbok "Klart slut varulvstjut" (andra exempel är "Tack och hej - leverpastej" och "Tjena, tjena - mittbena"). Dessa har blivit som ett signum för texterna och en "ingång" till den världsbild de förmedlar och i och med att dessa rim är lätta att lära sig utantill, upprättar de en förbindelse mellan text och läsare.

Till språkleken hör olika typer av hemliga språk, något som har långa tradition i pojkboken. Detta fenomen har en intimitetsskapande funktion, i och med att man avkodar meddelandet tillhör man den gemenskap som känner till dess innehåll. I Berts dagbok gäller det främst Berts täcknamn Treb, men här finns även eufemistiska varianter där aktiviteter som är förbjudna av vuxenvärlden ges nya namn, såsom rökning: "Klimpen kan strumpa strumpor genom näsan och göra strumpringar." (Jacobsson 1987, 42) Men här finns också parodier, där utsagan aldrig får någon förklaring: "Först lite på mitt hemliga språk: Konkakloff silibom pullen trejpe troff." (Jacobsson 1987, 73) 


\section{Ordvitsande och zeugmat}

I Bertböckerna finns vidare olika typer av ordvitsande. En av de vanligare är den komiska behandlingen av främmande ord, något som jag visat har tradition i pojkhumorgenren, bland annat hos Ebbe Lieberath (Öhrn 2008b, 308). Berts gammelfarmor var gift med en ryss, vilket ger upphov till omtydningar: "Spatsiba, säger gammelfarmor när hon tackar för maten. - Sportsida, säger jag." (Jacobsson 1987, 41) Till denna praktik kan också räknas stavfel, även det ett vanligt inslag i denna genre (som i sin tur är en realismmarkör som ger intryck av att historien berättas ur pojkarnas synvinkel). Ett flertal av Strömbergs böcker inleds med ett brev till utgivaren, exempelvis Två tjuvpojkar i skolan: "Snälla farbror Sigge! Härmed skickar jag manuskriftet till den nya boken och nu får jag be farbror vara snäll och ta bort dom värsta stafvelen och så trycka den som vanlikt." (Strömberg 1917, 7). I Berts dagbok undertecknar Bert ett gratulationskort med "otjänd person", för att ta ett exempel. Till denna kategori kan också räknas anglicismer, då de inte sällan blir felstavade, såsom "kobåjnamn" och "Rolls Rojs". De engelska låneorden har även blivit en naturlig del av ungdomarnas språkbruk, som att Åke är "hot" på en tjej (Jacobsson 1987, 40). När det gäller anglicismerna inom den litterära pojkhumorn går tankarna naturligtvis till Bengt Linders Danteböcker, i vilka ord som "pipel", "fejs" och "plejs" efterhand fick ett allt större utrymme i både huvudpersonernas och berättarens vokabulär.

I böckerna om Bert finns även exempel på ett mer avancerat vitsande. I Berts dagbok handlar det framförallt om zeugmat, en retorisk figur som innehåller en sammanokning av företeelser som inte är riktigt likvärdiga. Ett paradexempel på denna typ av vitsande är Falstaff, fakirs ord om Perssons änka, hon som tillbringade det första änkeåret i förtvivlan och det andra i Åmål. I Berts dagbok är denna typ av oortodoxa sammanställningar vanliga, som när det blir tårtkrig: "Jag var USA och Klimpen var Holland och Bo-Göran var ledsen." (57) Ofta dyker den upp som en slutknorr i några av de många räckorna, exempelvis i uppräkningen av de aktiviteter man kan välja på under en fridluftsdag: "åka slalom/åka längdskidor/ åka skridskor/åka hem (om man var förkyld)" (24).

Bertger exempel påhur man praktisktkan görabrukav språkleken: "Man kan ringa till personer med roliga namn. Här är några bra: - Är det Gran? - Ja? - Barra, då. HA HA HA! - Är det Örn? - Ja? - Flyg i väg, då." (33f) I vissa fall är vitsandet slutpunkt på vad som närmast är att likna vid en sketch, som när Rut berättar för klassen att hon ska gifta sig rikt när hon blir stor: "Min pappa är ledig, sa Åke. - Är han 
rik? frågade Rut. - Nej, men han spelar på hästar. - Vilka låtar kan han? skrek Torleif." (102f)

Förutom att man som läsare förevisas den konkreta nytta man kan ha av denna skämtande jargong, kommenteras den på olika sätt i texten, kommentarer som i sin tur pekar ut några av diskursens viktigaste ingredienser. Några vitsar åtföljs av anmärkningar som "(Fniss)" och "OBS! Skojigt skämt." (44, 120) Samma sak gäller rimmen: "Det där var ett rim. Rim är roliga." (101) Och slutligen understryks att engelskans betydelse: "Mormors syster Klara. Hon är tuff. Hon har bott i Amerika. - You know, säger hon efter varje mening. Det är bra." (72) Texten lär inte bara ut pojkdiskursen i allmänhet, man skolas också in i vad som är roligt.

\section{Avslutning: den intimitetsskapande pojkhumorn}

I Tarzan i slukaråldern skriver Conny Svensson angående Cromptons böcker: "Billböckernas stora popularitet även utanför huvudpersonens hemland måste bero på att de kunde förmedla något - jag vill inte kalla det allmänmänskligt, men snarare allmänpojkligt. De unga läsarna får sålunda ta del av det glädjande budskapet att just de befinner sig i människans bästa och lyckligaste ålder." (Svensson 1997, 100) Hans förklaring av begreppet" allmänpojkligt" är knappast uttömmande, men han är något på spåren.

Som jag sökt visa på olika sätt ovan upprättar diskursen i Bertböckerna en förbindelse med sina läsare, något som förmodligen kan sägas generellt om pojkhumorn som genre. Det finns olika tecken på att pojkhumorn i första hand riktar sig till just pojkar. På ett av försättsbladen till Berts dagbok läser man: "Död åt den som tjuvläser denna dagbok. Må han brinna i fasans eld." (min kurs.) Här utgår dagbokskrivaren från att det just är en han som kan tänkas vara intresserad, trots att han skriver i en traditionellt sett kvinnlig genre. Blickar man bakåt finner man liknande ingångar. Harry A:son, upptäcktsresande inleds med "Mors, grabbar!" (Westergren 1952, 3), medan den första Danteboken Dante, toppsmart kille (1966) lämnar en öppning för andra läsare: "Bästa blivande polare och eventuella brud som läser detta!" (Linder 1966, 5)

De läsare som tar del av dessa texter blir, om de låter sig omfattas av diskursen, "polare" med Bert, Dante eller Harry. Detta förhållande kan troligen delvis förklara böckernas popularitet. Läsarna upptas i en homosocialitet som både förenar och utestänger, eller för att uttrycka det som Thomas Johansson gör i Det första könet? (2000): "Begreppet homosocialitet har ofta använts för att analysera hur män sluter sig samman för att bevara sin makt, men jag menar att 
det är ett tudelat och ambivalent begrepp som kan användas för att beteckna makt såväl som gemenskap/intimitet." (Johansson 2000, 147)

Johansson menar att även om " homosocialiteten binder samman och stärker den manliga hegemonin", så "måste även män ibland utgå från en könsspecifik upplevelsevärld för att kunna agera i ett förändringsarbete." (148) Det vore förmätet att påstå att denna artikel ingår i ett sådant förändringsarbete. Men kanske kan den delvis utgöra en förutsättning för en dylik strävan, genom att den söker blottlägga det pojkarna skrattar åt och känner gemenskap inför, istället för att benämna det "ofog", "slapp och överenergisk jargong" eller "halvfrivola antydningar", såsom tidigare forskare. Möjligen kan en fördjupad studie av den pojkhumor som böckerna om Bert är en del av visa på subversiva undertexter, i likhet med de feministiskt inspirerade nyläsningarna av flickboken som kommit under senare år (Westin 1998, 135). Men med den viktiga skillnaden att en sådan subversiv rörelse i detta fall torde röra sig åt andra hållet, det vill säga en strävan bort från hegemoni och mot gemenskap och intimitet. Kanske skulle detta, för att tala med Johansson, "leda till att den stela manliga masken förvandlas till något mer uttrycksfullt och levande" (Johansson 2000, 148) - gissningsvis den känsla som Conny Svensson söker omfatta med begreppet "allmänpojklighet".

Biografisk information: Fil dr Magnus Öhrn, universitetslektor i litteraturvetenskap, särskilt barn- och ungdomslitteratur vid institutionen för litteraturvetenskap och idéhistoria vid Stockholms universitet.

Kontakt:magnus.ohrn@littvet.su.se

\section{Noter}

${ }^{1}$ Denna groteska trosförklaring lärde sig min svärfar (f.1938) på skolgården som pojke och kan den fortfarande utantill, något som visar på diskursens muntliga sida.

\section{Bibliografi}

Aldrich, Thomas Bailey. En stygg pojkes historia. övers. Karl Hemgren, Stockholm: Bonnier, 1880.

Andræ, Marika. Rött eller grönt? Flicka blir kvinna och pojke blir man i B. Wahlströms ungdomsböcker 1914-1944. Stockholm: B. Wahlström, 2001.

Bachtin, Michail. Rabelais och skrattets historia. François Rabelais' verk och den folkliga kulturen under medeltiden och renässansen. Gråbo: Anthropos, 1986.

Berggren, Mats. Kalsonger med gröna älgar. Stockholm: Rabén \& Sjögren, 1991. 
Blomqvist, Ylva. "Klämmiga pojkar. Fostran, ideal och modernisering i Ebbe Lieberaths scoutböcker". I Barnboken 1999:2, s 24-38.

Boëthius, Ulf. När Nick Carter drevs på flykten. Kampen mot "smutslitteraturen" i Sverige 1908-1909. Stockholm: Gidlund, 1989.

Boglind, Ann \& Nordenstam, Anna. Från fabler till manga. Litteraturhistoriska och didaktiska perspektiv på barn- och ungdomslitteratur. Malmö: Gleerup, 2010.

Byström, Dan. Julles sanna berättelser ur livet. Stockholm: Geber, 1936.

Edström, Vivi. Barnbokens form. En studie i konsten att berätta. Stockholm: Stegeland 1980.

Engqvist, Hans Erik. Rymmarna. Stockholm: Bonnier, 1978.

Falk, Hugo. Gösta Svärdfält och båtsman Våghals. Deras öden och äfventyr. En bok för pojkar. Stockholm: Bonnier, 1898.

Furuland, Lars, Ørvig, Mary \& Svensson, Sonja. Ord och bilder för barn och ungdom 3. Ungdomslitteraturen. Historik, kommentarer, texturval. Stockholm: Rabén \& Sjögren 1994.

Hellsing, Lennart. "Tjuvpojksboken". I Barnbok och barnboksforskning. Red. Lena Fridell. Stockholm: Almqvist \& Wiksell, 1972, s 31-40.

Jacobson, Marcia. Being a Boy Again. Autobiography and the American Boy Book. Tuscaloosa \& London: University of Alabama press, 1994.

Jacobsson, Anders \& Olsson, Sören. Berts dagbok. Stockholm: Rabén \& Sjögren, 1987.

Jacobsson, Anders \& Olsson, Sören. Berts bekännelser. Stockholm: Rabén \& Sjögren, 1992.

Jacobsson, Anders \& Olsson, Sören. Bert och kalla kriget. Stockholm: Rabén \& Sjögren, 2005.

Johansson, Thomas. Det första könet? Mansforskning som reflexivt projekt. Lund: Studentlitteratur, 2000.

Kidd, Kenneth B. Making American Boys. Boyology and the Feral Tale. Minneapolis \& London: University of Minnesota press, 2004.

Larson, Lorentz. Ungdom läser. En undersökning över läsintressena hos barn och ungdom $i$ åldern 7-20 år. Pedagogiska skrifter utgivna av Sveriges allmänna folkskollärarförenings litteratursällskap, häfte 195-198, 1947.

Lieberath, Ebbe. Gränsridare. En pojkbok. Göteborg: Ernst Bauer, 1917.

Linder, Bengt. Dante, toppsmart kille. Stockholm: B. Wahlström, 1966.

Linder, Bengt. Kolla skägget, Dante. Stockholm: B. Wahlström, 1968.

Linder, Bengt. Vicken panggrej, Dante. Stockholm: Semic, 1974.

Lundberg, Anna. Allt annat än allvar. Den komiska kvinnliga grotesken i svensk samtida skrattkultur. Göteborg \& Stockholm: Makadam, 2008.

Lundqvist, Sven. Uppfostran I skolåldern. 3. Tukten. Stockholm: Nordstedt, 1901. 
Lyman, Peter. "The Fraternal Bond as a Joking Relationship. A Case Study of the Role of Sexist Jokes in Male Group Bonding". I Changing Men. New Directions in Research on Men and Masculinity. Red. Michael S. Kimmel. London: Sage Prod., 1987, s 148-164.

Matthias, Adolf. Huru vi skola uppfostra våra söner. En bok för fäder och mödrar. Stockholm: Nordstedt, 1914.

Nikolajeva, Maria. "Det självutlämnande jaget. Den fiktiva dagboken i barn- och ungdomslitteraturen". I Barnlitteraturanalyser. Red. Maria Andersson och Elina Druker. Lund: Studentlitteratur, 2008, s 179-194.

Nordin, Magnus. Blodets röst. Stockholm: Bonnier Carlsen, 2010.

Norlander, Emil. Anderssonskans Kalle. Pojkstreck och kärringskvaller. Stockholm: Gullberg \& Hallberg, 1901.

Schwenger, Peter. "The Masculine Mode". I Speaking of Gender. Red. Elaine Showalter, New York: Routledge, 1989, s 101-112.

Strömberg, Sigge. Två tjuvpojkar i skolan. Ur Kalle Svenssons dagbok. Stockholm: Åhlén \& Åkerlund, 1917.

Svensson, Conny. Tarzan i slukaråldern. Stockholm: Rabén \& Sjögren, 1997.

Westergren, Bengt. Harry A:son, upptäcktsresande. Berättelse för pojkar. Stockholm: B. Wahlström, 1952.

Westergren, Bengt. Harry A:son, tigerjägare. Stockholm: B. Wahlström, 1955.

Westin, Boel. "Vad är barnlitteraturforskning?". I Litteraturvetenskap - en inledning. Red. Staffan Bergsten. Lund: Studentlitteratur, 2002, s 125-137.

Zetterström, Erik. Två år i varje klass. En elak skolgosses minnen. Stockholm: Åhlén \& Åkerlund, 1923.

Zweigbergk, Eva von. Barnboken i Sverige 1750-1950. Stockholm: Rabén \& Sjögren, 1965.

Öhrn, Magnus. "'Men vad i himlens namn har ni för er, pojkar!' Ulf Starks uppväxtskildringar ur ett manlighetsperspektiv". I Barnlitteraturanalyser.

Red. Maria Andersson och Elina Druker. Lund: Studentlitteratur, 2008a, s 131-148.

Öhrn, Magnus. "'Har du börjat ruttna i kolan?' - om värderingen av pojkdiskursen i svensk barn- och ungdomslitteratur". I Samlaren 129 (2008b), s 305-314.

Öhrn, Magnus. "Från mammas kjol till pappas like. Pojkdomens livslinje i äldre svensk barnlitteratur". I Livslinjer. Berättelser om ålder, genus och sexualitet. Red. Fanny Ambjörnsson och Maria Jönsson. Göteborg \& Stockholm: Makadam, 2010, s 182-201. 